\title{
The Impact of Commerce Circulation Agglomeration on China's Production Efficiency
}

\author{
Zijuan Gong \\ School of Economics and Management \\ Yiwu Industrial and Commercial College \\ 2Xueyuan Road Yiwu, Zhejiang, China, 322000 \\ E-mail: 64322676@qq.com
}

\begin{abstract}
By means of Chinese provincial data from 2003 to 2015, this paper conducts an empirical investigation into the impact of commerce circulation agglomeration on its production efficiency. The empirical results show that, in general, the agglomeration of commerce circulation promotes the development of its production efficiency. Taking into consideration the huge differences of commerce circulation agglomeration and its production efficiency in different regions of China, regression analysis has been further carried out by dividing the region into several parts. The empirical results show that the agglomeration of commerce circulation has a significant positive effect on the development of production efficiency in the central region and a limited influence on the eastern and western regions. In addition, other factors such as the level of financial development, innovation capacity, foreign capital inflows, and traffic conditions will also affect the efficiency of commercial circulation industry significantly.
\end{abstract}

Keywords-Agglomeration; Commercial circulation industry; Production efficiency; Empirical analysis

\section{INTRODUCTION}

As the important basis industry of economy development, the development status of industry impact on the economy has been concerned by many scholars. Yu Binbin and Yang Hongxiang (2015) [1] use the empirical data of the Chinese city to analysis the effect of agglomeration of manufacturing industry and service industry on regional economic efficiency. Their reaches showed that the agglomeration promote economic efficiency from the national level, but further, from the regional level, the role of the agglomeration to the economic efficiency in development region is more than other regions.By using Chinese provincial level data, Li Jian and Jiang Bao (2016)[2] analysis the impact of logistics industry cluster impact on economic efficiency and economic growth, the empirical results show that the logistics industry agglomeration significantly promote economic efficiency and economic growth, the impact of logistics industry cluster to the efficiency of the third industry is higher than that of other industries. Shu. Hui and Zhou Xideng (2014) [3] use empirical spatial panel datato analyze the logistics industrial agglomeration effect on TFP. They find that the logistics industry agglomeration reduces the transaction cost by specialization effect, and thus enhance the local TFP increase of production efficiency in other areas through spatial spillover effects.

In current, the agglomeration of commercial circulation industry is become increasingly. Can it affect the production efficiency of itself? There are no scholars have done the reaches on this specific problems, so this paper will do it by using the data of China provincial level.
II. THE EMPIRICAL ANALYSIS OF THE IMPACT OF THE AGGLOMERATION OF COMMERCIAL CIRCULATION ON ITS EFFICIENCY

\section{A. Model establishment}

$$
t f p_{i t}=\alpha+\beta_{1} \text { agglo }_{i t}+\sum \beta_{\text {controls }} \text { controls }_{i t}+\varepsilon_{i t}(1)
$$

TFP stands the total factor productivity of the trade circulation industry by DEA-Malmquist index calculation, Agglo represents the agglomeration level of the commercial circulation industry, controls on behalf of other influence factors of TFP of commercial circulation industry, i on behalf of the provinces, $\mathrm{t}$ represent the year, $\mathcal{E}$ on behalf of the error term. Based on the existing literature, this paper will look wholesale and retail as the representative of trade circulation industry [4].

\section{1) Interpreted variables}

Using DEA-Malmquist index method to calculate the TFP, we should select the input and output indicators. This paper chooses the capital stock and labor as the input index, the increased value of the wholesale and retail industry as the output index. The base value of capital stock (2003 capital stock $)=2003$ investment in fixed assets $\div(2003-2015$ the actual average growth rate of investment in fixed assets + the depreciation rate), the depreciation rate was $7 \%$. The capital stock of other years was calculated by perpetual inventory method: $K_{t}=I_{t}+(1-\delta) K_{t-1}$. We choose the number of employees of wholesale and retail as labor index.

\section{2) Core explanatory variables}

This paper uses the location entropy index to measure the agglomeration of trade circulation industry (agglo). The commercial circulation industry agglomeration (agglo) $=($ the increase value of commercial circulation industry of one area / GDP) $\div$ (national commercial circulation added value / the GDP). 


\section{3) Control variables}

Many factors affect the level of trade circulation efficiency; [5] this paper selects eight representative control variables. (1) the level of financial development (FINA), the ratio of deposit and loan balances and GDP, The higher the level of financial system, the commercial circulation enterprises can more easy to get the funds with low cost, and enhance production efficiency. (2) The scale of foreign capital inflow (FDI), the ratio of foreign direct investment and GDP. Foreign enterprises have advanced technology and higher productivity; they can affect the production efficiency of commercial circulation enterprises. (3) The urbanization (city), expressed by the ratio of urban resident population and the total population. Higher urbanization means the bigger scale of market demand and fierce competition, which force the enterprises to improve technology to improve the production efficiency. (4) The traffic (traff), expressed by the numeric value of the total mileage of traffic of one area. The more perfect the transport infrastructure, the lower the logistic cost, the higher the efficiency of product distribution, thereby affecting the efficiency of business enterprises. (5). Government intervention (gov), expressed by the ratio of fiscal expenditure and GDP. The level of government influence of circulation business will have great influence on the efficiency of commercial circulation. (6) The inflation rate (inflat), calculated by (the consumer price index of this year-consumer price index of last year) $\div$ the consumer price index of last year. The lower the inflation rate is, the more stable the economic environment, the easier the commercial circulation enterprises to develop activities, and continuously improve the technology, enhance market competitiveness, and then affect the production efficiency. (7) The level of Education (EDU), represented by the numeric value of the average number of years of education. The level of average education directly related to the skill level of workers, thereby affecting the production efficiency of commercial circulation industry. (8) The level of science and technology development (patent), expressed by the numeric value of the number of patents. The level of science and technology development, related to the ability of improving the technology and production efficiency of circulation enterprises in this area [6].

\section{B. Data sources and descriptions}

The data used in this paper come from the statistical yearbook of China's population and employment in the past 2003-2015 years, the statistical yearbook of China, the website of the National Bureau of statistics and the database of China economic network. The regression data in Table 1 show the descriptive statistical results of variables.

TABLE I VARIABLE DESCRIPTIVE STATISTICS

\begin{tabular}{|c|c|c|c|c|c|}
\hline variable & Sample size & Average value & standard deviation & Minimum value & Maximum value \\
\hline $\mathrm{tfp}$ & 372 & 0.97432 & 0.147173 & 0.553 & 2.025 \\
\hline agglo & 403 & 1.008636 & 0.262013 & 0.489596 & 1.78445 \\
\hline fina & 403 & 2.667967 & 2.647073 & 1.07171 & 51.9405 \\
\hline fdi & 403 & 0.396058 & 0.512388 & 0.04733 & 5.70538 \\
\hline city & 403 & 0.487091 & 0.144406 & 0.081508 & 0.896 \\
\hline traff & 403 & -0.58843 & 0.964442 & -3.39255 & 0.915322 \\
\hline gov & 403 & 0.226789 & 0.174573 & 0.079176 & 1.34594 \\
\hline inflat & 403 & 0.102985 & 0.052665 & -0.5184 & 0.424 \\
\hline edu & 403 & 2.118741 & 0.158334 & 1.31866 & 2.491609 \\
\hline patent & 403 & 8.663693 & 1.772672 & 2.772589 & 12.50597 \\
\hline
\end{tabular}

\section{Empirical results and analysis}

First, we use panel data of China 31 provinces, municipalities and autonomous regions of 13 years to general regression, use three kind of regression methods: fixed, random and mixed effects, the regression results shown in Table 2.The Housman and F test showed that the fixed effect method is optimal, this article analysis the fixed effects regression results intable 2 . In column (1), we found that the commercial circulation industry agglomeration significantly promote the production efficiency improvement. The promotion role of agglomeration on the production efficiency of the commercial circulation industry can mainly be summarized as follows: firstly, in commercial circulation industry gathering place, the market competition is fierce; the survival pressure forced the enterprises to improve production technology and management to improve their production efficiency, and win in the fierce market. Secondly, in commercial circulation industry gathering place, gathering a large number of outstanding talent, these people have received professional and rigorous training in other commercial enterprises, so the commercial enterprises can quickly hire these talents without additional training, thus increase the production efficiency of the enterprise. In addition, in commercial circulation gathering place, the related facilities provided by the government are often more perfect, so the enterprise can use these facilities more convenient to smoothly carry out the production and business activities, and enhance the production efficiency of the enterprise.

In control variables, the level of financial development (FINA) coefficient is positive and significant at $1 \%$ of the significance levels, which indicates that the improvement level of financial development significantly enhance the production 
efficiency of circulation industry. With the improvement of financial development, the ability of financial services to social and economic development is stronger, the trade circulation industry is easier to get financial support, and then use these funds to expand the scale of production and improve the technical level, and enhance the circulation efficiency. The foreign capital inflow scale (FDI) coefficient is positive and significant at $1 \%$ of the significance levels, which indicates that the inflow of foreign capital promote the promotion of production efficiency of commercial circulation industry. The foreign enterprises has been operating for many years in the foreign market, they have advanced technology and management experience, after entering China, they can effectively promote the production efficiency of commercial circulation industry through technology spillover effect. The development level of transportation (traff) coefficient is positive and significant at $5 \%$ of the significance levels, which indicates that the improvement of transportation infrastructure significantly promote the production efficiency of the commercial circulation industry. Perfect infrastructure can effectively enhance the efficiency of delivery of products, reduce transportation costs, and enhance the production efficiency of commercial circulation industry.

TABLE II BASIC REGRESSION RESULTS

\begin{tabular}{|c|c|c|c|}
\hline & $\begin{array}{c}\text { (1) } \\
\text { fixed }\end{array}$ & $\begin{array}{c}(2) \\
\text { stochastic }\end{array}$ & $\begin{array}{c}(3) \\
\text { mixed }\end{array}$ \\
\hline \multirow[t]{2}{*}{ cenval } & $0.283^{* *}$ & $0.170^{* * *}$ & $0.153^{* *}$ \\
\hline & $(0.114)$ & $(0.0752)$ & $(0.0739)$ \\
\hline \multirow[t]{2}{*}{ fina } & $0.00240^{* * * *}$ & $0.00240^{* * * *}$ & $0.00275^{* * * *}$ \\
\hline & $(0.000604)$ & $(0.000485)$ & $(0.000613)$ \\
\hline \multirow[t]{2}{*}{ patent } & -0.0163 & -0.0121 & -0.0111 \\
\hline & $(0.0325)$ & $(0.0154)$ & $(0.0140)$ \\
\hline \multirow[t]{2}{*}{ inflat } & 0.00900 & 0.0953 & 0.107 \\
\hline & $(0.0867)$ & $(0.0947)$ & $(0.0958)$ \\
\hline \multirow[t]{2}{*}{ fdi } & $0.0279^{*}$ & -0.00415 & -0.0144 \\
\hline & $(0.0144)$ & $(0.0174)$ & $(0.0167)$ \\
\hline \multirow[t]{2}{*}{ city } & -0.359 & -0.169 & -0.112 \\
\hline & $(0.215)$ & $(0.134)$ & $(0.130)$ \\
\hline \multirow[t]{2}{*}{ traff } & $0.106^{* *}$ & -0.00530 & -0.0101 \\
\hline & $(0.0442)$ & $(0.0222)$ & (0.0196) \\
\hline \multirow[t]{2}{*}{ edu } & -0.176 & 0.196 & 0.197 \\
\hline & $(0.317)$ & $(0.152)$ & $(0.139)$ \\
\hline \multirow[t]{2}{*}{ gov } & 0.205 & 0.000780 & -0.0114 \\
\hline & $(0.121)$ & $(0.0612)$ & $(0.0603)$ \\
\hline \multirow[t]{2}{*}{ constant } & $1.379^{* * *}$ & $0.560^{\text {** }}$ & $0.541^{* *}$ \\
\hline & $(0.505)$ & $(0.262)$ & $(0.243)$ \\
\hline sample number & 372 & 372 & 372 \\
\hline$R^{2}$ & 0.118 & 0.176 & 0.069 \\
\hline
\end{tabular}

Because the efficiency and agglomeration of business circulation industry in different area is different, this paper further divided empirical regression into the eastern, central and western sets in order to analysis the impact of agglomeration on commercial circulation efficiency reasonably. From table 3 , we find that the trade circulation industry agglomeration significantly promote the production efficiency of commercial circulation industry of the central region, while no significant effect on the eastern and central regions. Because of the economic restructuring, the eastern region has put more resources into high-end manufacturing and services industry. Lack of commercial circulation industry resources, it is difficult to form an effective concentration, thereby affecting the production efficiency improvement. Now the central region is seeking the economic scale growth, the demand for commercial circulation of capital and technology is small, it is easy to get rapid development, in addition, Part of business circulation industry in the eastern region is also transferred to the central region, all of these promote trade circulation industry agglomeration effectively in the eastern region, then enhance the production efficiency. The western region's economic scale is small, correlation facilities is backward, development of commercial circulation industry in the region is slow, so it is difficult to form an effective concentration, and the impacts on the commercial circulation industry production efficiency is not significant too.

In control variables, the level of financial development (FINA) coefficients is positive and significant at the $1 \%$ significance level, which indicates that the improvement of the level of financial development significantly promoted the production efficiency of commercial circulation industry in the western region, but had no significant effects on the eastern and central regions. The level of financial development in the eastern and central region is far higher than the western region, with financial development the funds which flow into commercial circulation industry is small, thereby the effects on production efficiency is not significant. In western region, the 
industrial structure is single, large capital inflows promote the production efficiency of the industry. The promotion of scale of foreign capital inflow (FDI) had a role in promoting the efficiency of trade circulation industry in the eastern region, and has inhibitory effect on the efficiency of the western region. The improvements of transportation infrastructure (traff) had a role in promoting the efficiency of commercial circulation industry in central region, but not significantly affect the production efficiency of the East and western region. The construction of infrastructure in eastern region is very perfect, so it is not important factors in promoting commercial circulation efficiency. With the rapid economic development of the central region, the transportation infrastructure rapidly improved, it reduces logistics costs, and promotes the production efficiency of the commercial circulation industry. In western region, the economic aggregate is small; the transport network density is low, so it is hard to have a significant impact on the production efficiency of commercial circulation industry.

TABLE III REGIONAL REGRESSION RESULTS

\begin{tabular}{|c|c|c|c|}
\hline & $\begin{array}{c}\text { (1) } \\
\text { East section }\end{array}$ & $\begin{array}{c}\text { (2) } \\
\text { Central section }\end{array}$ & $\begin{array}{c}(3) \\
\text { West section }\end{array}$ \\
\hline \multirow[t]{2}{*}{ agglo } & 0.182 & $0.720^{* * *}$ & 0.239 \\
\hline & $(0.148)$ & $(0.136)$ & $(0.311)$ \\
\hline \multirow[t]{2}{*}{ fina } & -0.0103 & -0.0269 & $0.00300^{* * *}$ \\
\hline & $(0.0451)$ & $(0.0529)$ & $(0.000861)$ \\
\hline \multirow[t]{2}{*}{ patent } & 0.0446 & 0.0123 & $-0.102^{*}$ \\
\hline & $(0.0829)$ & $(0.0940)$ & $(0.0519)$ \\
\hline \multirow[t]{2}{*}{ inflat } & -0.0111 & -0.0513 & -0.153 \\
\hline & $(0.113)$ & $(0.367)$ & $(0.101)$ \\
\hline \multirow[t]{2}{*}{ fdi } & $0.0301^{*}$ & -0.371 & $-0.195^{* * *}$ \\
\hline & $(0.0139)$ & $(0.340)$ & $(0.0659)$ \\
\hline \multirow[t]{2}{*}{ city } & -0.354 & -0.564 & 0.327 \\
\hline & $(0.249)$ & $(1.480)$ & $(0.779)$ \\
\hline \multirow[t]{2}{*}{ traff } & 0.0700 & $0.217^{* * *}$ & 0.0822 \\
\hline & $(0.0792)$ & $(0.0689)$ & $(0.0760)$ \\
\hline \multirow[t]{2}{*}{ edu } & -1.304 & 0.226 & 0.115 \\
\hline & (1.123) & $(0.442)$ & $(0.261)$ \\
\hline \multirow[t]{2}{*}{ gov } & 0.471 & -0.751 & 0.358 \\
\hline & $(0.871)$ & $(0.985)$ & $(0.261)$ \\
\hline \multirow[t]{2}{*}{ constant } & 3.368 & 0.306 & $1.189^{* *}$ \\
\hline & $(1.930)$ & $(0.746)$ & $(0.413)$ \\
\hline sample number & 132 & 108 & 132 \\
\hline$R^{2}$ & 0.133 & 0.268 & 0.164 \\
\hline
\end{tabular}

\section{CONCLUSION}

This paper uses the provincial level data in China during the 2003-2015 years to analysis the trade circulation industry agglomeration effect on its efficiency. The results showed that agglomeration is conducive to the promotion of commercial circulation efficiency from the overall level of China. Further regression from the regional level found: the trade circulation industry agglomeration significantly promote the production efficiency of commercial circulation industry of the central region, while no significant effect on the eastern and central regions. In addition, some other factors also affect the efficiency of the circulation industry.

According to the empirical results, this paper thinks that the government should support the agglomeration of commercial circulation, increase the investment of industry employment skills training and transportation infrastructure, which is conducive to the promotion of business circulation industry agglomeration, and give full play to the promotion role of agglomeration on efficiency of the business circulation industry.

\section{REFERENCE}

[1] Yu Binbin,Yang Hongxiang and Jin Gang. Can industrial agglomeration improve regional economic efficiency? -- Based on the spatial econometric analysis of Chinese urban data [J]. Journal of Zhongnan University of Economics and Law, 2015, 210 (3): 121-130. (In Chinese)

[2] Li Jian, Jiang Bao. The impacts of logistics industry agglomeration on regional economic growth -- Based on spatial econometric analysis of inter provincial data $[\mathrm{J}]$. Journal of Central South University (SOCIAL SCIENCE EDITION), 2016, 22 (4): 103-110.(In Chinese)

[3] Shu Hui, Zhou Xi Deng, Lin Xiaowei. Logistics industry agglomeration and total factor productivity growth-spatial econometric analysis based on provincial data [J]. Journal of Central University of Finance and Economics, 2014, 1 (3): 98-105. (In Chinese)

[4] Yuwen Dong, Xu Congcai. Study on the transition of growth pattern of Chinese trade circulation industry-the perspective of total factor productivity $[\mathrm{J}]$. Journal of Beijing Technology and Business University (SOCIAL SCIENCE EDITION), 2017, 32 (1): 31-41. (In Chinese)

[5] Yufeng chen, Wubin zhang, The Evolution trend and influencing factors of China's Regional Trade Circulation efficiency [J]. Industrial economy research 2015(1):53-60. (In Chinese)

[6] Moreno J D J, Carrasco O R. Evolution of efficiency and its determinants in the retail sector in Spain: new evidence [J]. Journal of Business Economics \& Management, 2015, 16(1):244-260. 